\title{
The knowledge map as a management tool for the perception of occupational health and safety for construction facul tiles students.
}

\author{
Jerzy OBOLEWICZ *1, Adam BARYŁKA ${ }^{1}$, Monika SZCZERBAK², and Anna \\ KUCZYŃSKA-CESARZ ${ }^{2}$ \\ ${ }^{1}$ Instytut Naukowy IBOA, Warsaw, Poland \\ ${ }^{2}$ Military University of Technology, Warsaw, Poland
}

\begin{abstract}
Work constitutes a fundamental dimension of human existence on earth. Humans plan, organize, perform work and thus develop through the work of their mind and the physical transformation of the world. Knowledge management has become a widely discussed and increasingly popular concept worldwide. The essence of this concept is the creation and dissemination of knowledge, understood as the entire content existing in the human mind as a result of accumulated learning and experience. The article presents a knowledge map as a management tool for the perception of occupational health and safety and health for construction faculties' students.
\end{abstract}

Keywords: construction, occupational health and safety, knowledge map, students perception of OHS

\section{Introduction}

Knowledge management has become a widely discussed and increasingly popular concept worldwide. The essence of this concept is the creation and dissemination of knowledge, understood as the entire content existing in the human mind as a result of accumulated learning and experience. This concept can be particularly useful in preparing students for their future career in the construction sector as a specific form of education. The specificity results mainly from the conditions in which the construction process is carried out. The specific features of the construction process include:

- individual character of each construction;

- significant scattering of the construction works in the field;

- real estate of construction products;

- dependence on atmospheric influences;

- late achievement of the effects of building facilities;

- large dimensions and large mass of building structures;

- long service life of buildings;

- random nature of the execution time of construction processes.

When students finish their studies we can observe a common phenomenon, so-called "Disappearance of knowledge". Students leaving the university are associated with the percentage loss of the knowledge they have been acquiring. Practically, instead of using the information acquired during studies, a university graduate taking up a job begins a new education process rather than completing the already existing knowledge. In the construction sector, the area of knowledge resulting from the specificity of the construction process has become more extensive after Poland's accession to the EU. It covers all stages of the investment process, from preparation of the investment to execution, implementation of the investment (construction process) and ending with usage (operation). Construction companies operating in the EU aim to achieve a specific goal. To list a few - it could be: economic profit, temporary durability

*Corresponding author: E-mail address: obolewiczjerzy@gmail.com (Jerzy OBOLEWICZ)

https://doi.org/10.37105/iboa.106

Received 2 November 2020

Available online 31 March 2021

ISSN 2450-1859, eISSN 2450-8721

Published by Centrum Rzeczoznawstwa Budowlanego 
or the well-being of its employees. As a rule, entrepreneurs adjust their activities to the environmental conditions by producing and delivering products and services to the market [14, 22].

In construction, production can be traditional or design-based [19]. Traditional production is a logical process widely recognized in the EU: design - production - sale of a product. In project-based production, the traditional order is done by: selling the idea to the client (investor) - signing the contract - developing a unique product adjusted to the changing customer requirements. From this perspective, the project is treated as a temporary organization of activities carried out in order to create a unique product or service. Production takes place on the basis of completed products and focuses on temporary teams whose members, functioning in a specific structure, strive to achieve a common goal $[7,8]$.

In the industry of the EU countries, including Poland, projects are implemented mostly sporadically, as enterprises are not prepared to work in accordance with the process approach [15]. This is due to their use of traditional organizational structures. Projects are carried out by permanent teams regardless of the normal production of the enterprise.

Companies using project management can conduct their activities according to two types of processes: business and project. Business processes are continuous and repetitive activities, resulting in routine activities, which affect the achievement of formalization and standardization. However, within design processes, these are activities that are not based on routine activities and are not largely repetitive. There is then no possibility of improvement or standardization [24].

In the European construction market, projects are managed by organizations prepared for both forms of activity [2]. They include the normal (business) activity of the enterprise, which responds to orders placed on the market or signing a contract. Working teams are not permanent. Project management at the production level coexists with management by projects. The construction production process involves many participants appointed by investors, designers, contractors or subcontractors who cooperate with each other in the pursuit of a common goal [21]. This situation results from the dynamics of the construction market, where companies have to constantly adapt their organization to the requirements of the environment resulting from the lack of continuity of production, e.g. by signing new contracts.

Construction companies, by carrying out specific construction works, transform projects into objects - infrastructure elements that begin with receiving an order or signing a contract with a client. Implementation of construction works is based on a design agreed and approved between the parties. The site where the works are carried out is located where the given infrastructure element is being built. Such activities cause that construction companies carry out works on various construction sites where works are planned in the project. When carrying out a given project, the construction company also coordinates the activities of suppliers and subcontractors who provide the necessary resources, such as: labor (own or subcontracted), machinery and equipment (own or subcontracted), materials, vehicles and office space.

Knowledge management aims to protect the organization against negative phenomena that threaten the achievement of a set goal and the effective use of intellectual capital in the company's operations. This is of great importance, particularly in the construction industry. Construction companies operate in a rapidly changing environment, face very high competition and are dependent on their customers' decisions. Such conditions require great flexibility and the ability to adapt to changing circumstances. Therefore, tools supporting decision-making in the field of construction company management are needed. With the development of the concept based on knowledge management, many management tools have been studies and developed. The views of specialists and experts became the starting point for building the concept of a knowledge map, a tool supporting decision-making processes, especially for businesses in the construction industry $[5,6,9]$.

\section{The concept of a occupational health and safety knowledge map (ohs knowledge maps)}

The concept of knowledge is one of the most difficult to define, the interpretation of which very often depends on the way it is being used. Most often, the term "knowledge" is understood as an organized set of information along with the rules for interpreting it [12]. The necessity of the skillful use of knowledge and increasing its resources prompts enterprises to constantly search for new tools related to this field. Collecting data and information alone is not enough. The enterprise must ensure that data and information are turned into knowledge. Properly processed data can become information, and processed and structured information can be transformed into knowledge, which is closely related 
to the processes specific to a given company. In relation to construction companies, knowledge can be recognized in many aspects, e.g. technological, resource, financial, organizational. The acquired information and its connections enable effective communication and learning about knowledge in various sections and with a varying degree of detail [10]. The knowledge map is a tool whose main task is to facilitate the effective sharing of knowledge between members of a given community, i.e. company employees, and between the community and external organizations. As knowledge is constantly changing, the knowledge map should be a dynamic, interactive and evolving tool [7].

In the literature on the subject, there are various types of knowledge maps. They are used in various fields and in the design of technical devices, and more and more often in education $[11,16-18]$. The concept of the knowledge map is modeled on cartographic maps in a three-dimensional system (Fig. 1).

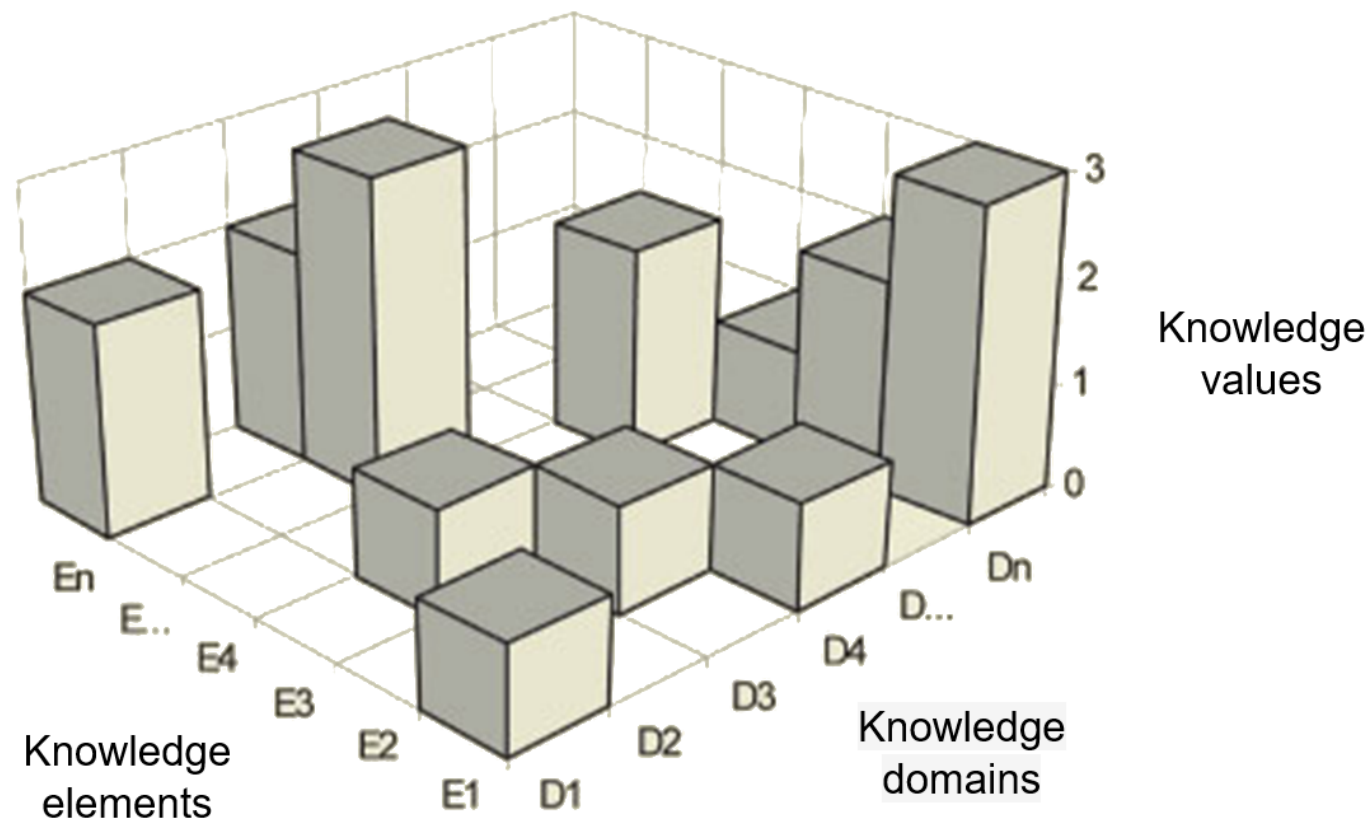

Figure 1. Knowledge map in a universal approach

The basis of the knowledge map is marked on the "x" axis of the domain (D) and on the "y" axis, knowledge elements (E), and on the " $z$ " axis, the value of knowledge is given, expressed in points, percentages, decimal numbers or other units (Fig. 1 ).

The presented situation illustrates the state of deficiencies in the required knowledge in specific elements, which means that knowledge should be supplemented within a certain time. Knowledge gaps can be caused by defective education and the aging of knowledge in the long term due to the fact that education does not keep up with the changing legal regulations and technical progress.

The analysis shows that the knowledge map may contain various elements distinctive to a selected industry or a specific company. Based on the literature and practice regarding the observation of solutions used in construction companies, it appears that the map of knowledge should start with the first element: the system and the environment - defining the company's mission and goals. Then there may be threats, resources, legal and technical requirements, market requirements, technical preparation, project processes, logistics, planning, documents, indications, to the last element of the map concerning changes, defining the register of all activities related to the operation of the knowledge map, including reasons and dates of changes in effect [20].

Currently, due to the practiced process approach to enterprise management, it is recommended that knowledge maps emphasize processes specific to a given enterprise. Among the processes, the most popular are the processes related to financial issues, then personnel, logistics, as well as the processes of quality system audit and business plan development [23]. The given sequence of processes determines the direction of interests of the owner of the knowledge map. Particular interest in the financial area results from the complex solutions used in the financial management of construction industry companies, the mode and scope of their analysis, accounting systems, organization and course of processes in the field of financial control and external audit, as well as the financial and management accounting tools 
used to improve the broadly understood management process. In construction companies, significant in the area of financial issues are, for example, those that relate to the calculation of the cost of manufacturing construction services, settlement of the costs of these services for the purposes of shaping the price generating sales revenues affecting the level of profitability, or the use of appropriate cost accounting that allows optimal cost accounting to achieve a positive financial result. The effectiveness of the decision-making process and the policy in the field of cost level shaping is ensured by the cost accounting properly adjusted to the specifics of the enterprise's activity. Many variations of cost accounting in use predict different dependencies between the factors of production, which have a direct impact on the level of costs. Hence, the knowledge of solutions in this area enables managers to make the right decisions directly related to the achieved results. In the practice of economic life, entrepreneurs may use traditional cost accounting models and other models to achieve various goals [13].

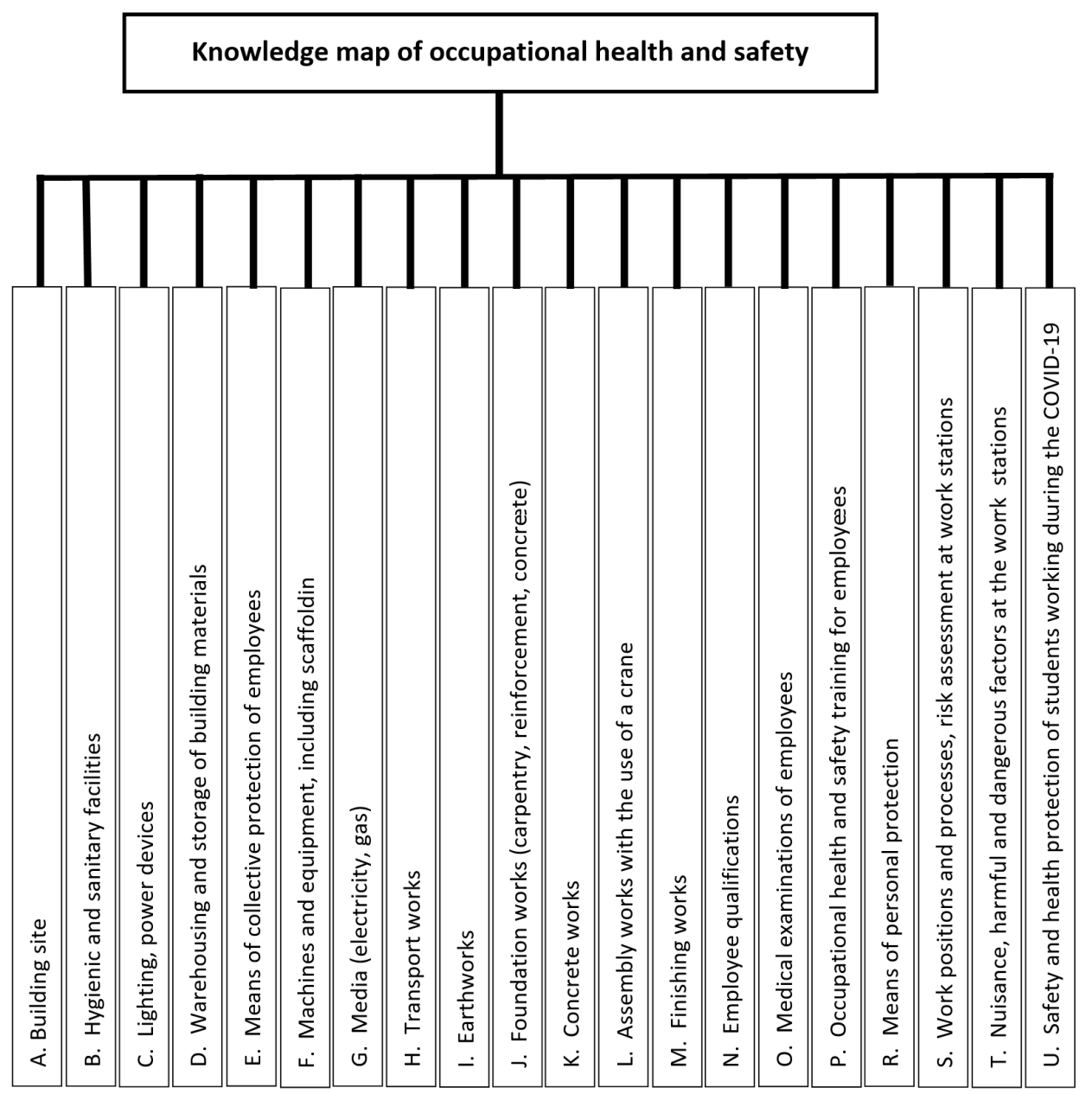

Figure 2. Structure of the occupational health and safety knowledge map

At this point, it is necessary to emphasize the multidimensionality of the protection of economic transactions, which entails the need for consistency of regulations from various areas of the applicable law. The security of economic transactions, expressed, inter alia, in the economic security in terms of macro and micro, can be verified in various ways. One of them is the financial review (financial audit) providing reliable, proven and consistent information on the economic and financial situation of operating organizations in the economy [1, 3, 4]. As part of the audit, in accordance with the International Standards on Auditing (ISAs), areas of threats to the functioning of the enterprise are identified and assessed. In the construction industry, the issue of hazards, including accidents, is particularly important. The ohs knowledge map may be a tool enabling the identification and diagnosis of threats.

The ohs knowledge map is a record of domain knowledge, in which 20 areas of knowledge have been designated and marked with symbols: A, B, C, D, E, F, G, H, I, J, K, L, M, N, O, P , R, S, T, U. Knowledge elements were assigned to the domains of knowledge and marked with symbols Ej. The structure of the map with the specified areas of knowledge is shown in Fig. 2. 
The issues of financial aspects can be referred to the knowledge map of ohs in all 20 areas of knowledge, as in each area there is a problem of ensuring the financial back-up guaranteeing the efficient functioning of all elements of the map's structure. Taking into account the fact that in the construction industry, the issues of safety and health protection are associated with almost every activity of creating a building object - an element of infrastructure, the authors decided to develop a questionnaire (table 1) to study the perception of occupational safety and health of students of construction faculties.

\section{Survey questionnaire for the student}

For research on the perception of occupational health and safety in the building trade Instruction:

Please choose one of the following options, marked with an $\mathrm{X}$ in the appropriate box. For each issue (question), please give a meaningful meaning (the significance of the given issue for the occupational health and safety of students, giving them weight on the following scale:

- high importance - 4;

- medium importance - 3;

- low importance - 2;

- does not matter - 1

Table 1. Questionnaire for researching the perception of occupational health and safety of students of construction faculties

\begin{tabular}{|c|c|c|c|c|c|c|}
\hline No. & Questions about the studied issue & 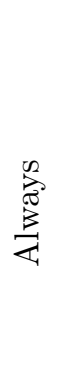 & 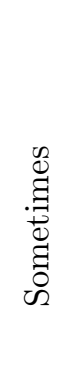 & 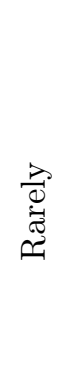 & 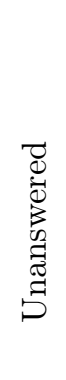 & 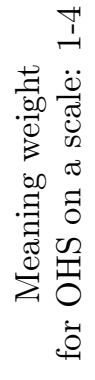 \\
\hline$-1-$ & $-2-$ & $-3-$ & $-4-$ & $-5-$ & $-6-$ & $-7-$ \\
\hline \multicolumn{7}{|c|}{ Preparation and organization of construction } \\
\hline A. & \multicolumn{6}{|l|}{ Building site and organization of construction } \\
\hline A.1 & $\begin{array}{l}\text { Has been / was / is the construction site secured against unau- } \\
\text { thorized access? }\end{array}$ & & & & & \\
\hline A. 2 & $\begin{array}{l}\text { Are there designated parking spaces for vehicles used by employ- } \\
\text { ees? }\end{array}$ & & & & & \\
\hline A.3 & $\begin{array}{l}\text { Are there designated (hardened and drained) places for outdoor } \\
\text { storage of building materials and products needed for classes? }\end{array}$ & & & & & \\
\hline A. 4 & $\begin{array}{l}\text { Do pedestrianized roads, ramps, walkways, exits and entrances } \\
\text { meet the health and safety requirements? }\end{array}$ & & & & & \\
\hline B. & \multicolumn{6}{|l|}{ Hygienic and sanitary facilities } \\
\hline B.5 & Are hygienic and sanitary facilities provided? & & & & & \\
\hline C. & \multicolumn{6}{|l|}{ Lighting, power devices } \\
\hline C.6 & Are the passages and danger zones illuminated? & & & & & \\
\hline C.7 & $\begin{array}{l}\text { Do the electric power distribution and consumption installations } \\
\text { not constitute a fire or explosion hazard and sufficiently protect } \\
\text { against electric shock? }\end{array}$ & & & & & \\
\hline C.8 & $\begin{array}{l}\text { Are electrical installations and devices protected against electric } \\
\text { shock and against direct and indirect contact? }\end{array}$ & & & & & \\
\hline C.9 & $\begin{array}{l}\text { Has the effectiveness of protection against electric shock been con- } \\
\text { firmed by measurements? }\end{array}$ & & & & & \\
\hline
\end{tabular}


Table 1. Questionnaire for researching the perception of occupational health and safety of students of construction faculties

\begin{tabular}{|c|c|c|c|c|c|c|}
\hline No. & Questions about the studied issue & 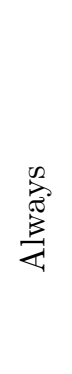 & 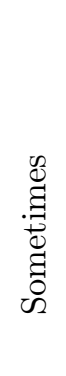 & 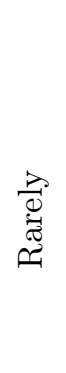 & 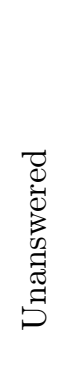 & 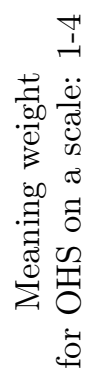 \\
\hline$-1-$ & $-2-$ & $-3-$ & $-4-$ & $-5-$ & $-6-$ & $-7-$ \\
\hline C.10 & $\begin{array}{l}\text { Are the electrical switchboards properly arranged, set up and se- } \\
\text { cured? }\end{array}$ & & & & & \\
\hline C.11 & $\begin{array}{l}\text { Are the cables supplying electrical devices protected against me- } \\
\text { chanical damage? }\end{array}$ & & & & & \\
\hline C.12 & $\begin{array}{l}\text { Are the connections of electrical equipment to electrical switch- } \\
\text { boards made in a manner ensuring safety? }\end{array}$ & & & & & \\
\hline C.13 & Are there periodic safety inspections of electrical devices on site? & & & & & \\
\hline D. & Warehousing and storage of building materials & & & & & \\
\hline D.14 & Were there designated storage areas for materials? & & & & & \\
\hline D.15 & $\begin{array}{l}\text { Were the required distances from overhead power lines maintained } \\
\text { during storage? }\end{array}$ & & & & & \\
\hline D.16 & Were the bulk materials properly warehouse and / or stored? & & & & & \\
\hline D.17 & $\begin{array}{l}\text { Did the shelves on which the materials were stored had adequate } \\
\text { strength and a stable structure? }\end{array}$ & & & & & \\
\hline D.18 & $\begin{array}{l}\text { Did the method of storing materials on shelves and their removal } \\
\text { pose a threat to the safety of employees? }\end{array}$ & & & & & \\
\hline D.19 & $\begin{array}{l}\text { Were materials, objects, hazardous substances and chemical } \\
\text { preparations and materials of the highest mass stored on the low- } \\
\text { est shelves? }\end{array}$ & & & & & \\
\hline E. & Means of collective protection of employees & & & & & \\
\hline E.20 & $\begin{array}{l}\text { Were railings installed while the work was being carried out in } \\
\text { places accessible to the unemployed? }\end{array}$ & & & & & \\
\hline E.21 & $\begin{array}{l}\text { Are communication routes and workstations located more than } 1 \\
\text { m above the site secured with a balustrade? }\end{array}$ & & & & & \\
\hline E.22 & $\begin{array}{l}\text { Are the danger zones fenced and marked in a way that prevents } \\
\text { access by unauthorized persons? }\end{array}$ & & & & & \\
\hline E.23 & $\begin{array}{l}\text { Do machines and other technical devices as well as mechanized } \\
\text { tools and moving parts of machines ensure safe working condi- } \\
\text { tions, e.g. through the use of covers or screens? }\end{array}$ & & & & & \\
\hline F. & Machines and equipment, including scaffolding & & & & & \\
\hline F.24 & $\begin{array}{l}\text { Have OHS instructions for the operation of machines and devices } \\
\text { been developed and made available for permanent use? }\end{array}$ & & & & & \\
\hline F.25 & $\begin{array}{l}\text { Were the machines and devices in use marked with appropriate } \\
\text { safety signs and colors? }\end{array}$ & & & & & \\
\hline F.26 & $\begin{array}{l}\text { Did the machines and devices used have appropriate protective } \\
\text { devices? }\end{array}$ & & & & & \\
\hline F.27 & $\begin{array}{l}\text { Have the machines and devices been certified with a safety mark } \\
\text { or a declaration of conformity? }\end{array}$ & & & & & \\
\hline
\end{tabular}


Table 1. Questionnaire for researching the perception of occupational health and safety of students of construction faculties

\begin{tabular}{|c|c|c|c|c|c|c|}
\hline No. & Questions about the studied issue & $\sum_{i}^{\infty}$ & 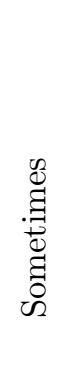 & 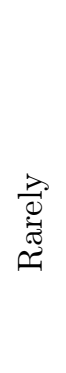 & 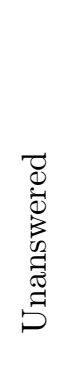 & 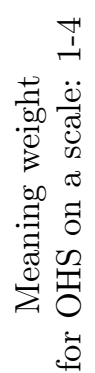 \\
\hline$-1-$ & $-2-$ & $-3-$ & $-4-$ & $-5-$ & $-6-$ & $-7-$ \\
\hline F.28 & $\begin{array}{l}\text { Were the machines and devices in use in a proper technical con- } \\
\text { dition? }\end{array}$ & & & & & \\
\hline F.29 & $\begin{array}{l}\text { Do machines and devices subject to supervision have the certifi- } \\
\text { cates of admission to traffic? }\end{array}$ & & & & & \\
\hline F.30 & Were the ladders in use in a proper technical condition? & & & & & \\
\hline F.31 & Were the tools in use in the proper technical condition? & & & & & \\
\hline F.32 & Was the scaffolding documented before it was put into service? & & & & & \\
\hline F.33 & Were the scaffolds properly placed on the ground? & & & & & \\
\hline F.34 & $\begin{array}{l}\text { Are the working surfaces of the scaffolding filled with the appro- } \\
\text { priate platforms? }\end{array}$ & & & & & \\
\hline F.35 & $\begin{array}{l}\text { Have the scaffolding been properly anchored to the fixed elements } \\
\text { of the structure? }\end{array}$ & & & & & \\
\hline F.36 & $\begin{array}{l}\text { Were communication lines between the levels of the scaffolding } \\
\text { platforms built? }\end{array}$ & & & & & \\
\hline F.37 & Have the scaffolding platforms fencing been made correctly? & & & & & \\
\hline F.38 & Have the scaffolding been used as intended? & & & & & \\
\hline F.39 & Have the scaffolding been periodically maintained and inspected? & & & & & \\
\hline F.40 & Did the metal scaffoldings have lightning protection? & & & & & \\
\hline G. & \multicolumn{6}{|l|}{ Media (electricity, gas) } \\
\hline G.41 & $\begin{array}{l}\text { Are the university's electricity distribution installations (wires, } \\
\text { receivers, connections, etc.) secured in such a way as to protect } \\
\text { students against electric shock and do not constitute a fire and } \\
\text { explosion hazard? }\end{array}$ & & & & & \\
\hline G.42 & $\begin{array}{l}\text { Did the gas installations, e.g. compressed air, oxygen for gas } \\
\text { welding, etc., meet the safety and health requirements? }\end{array}$ & & & & & \\
\hline \multicolumn{7}{|c|}{ Health and safety requirements during the performance of works } \\
\hline H. & \multicolumn{6}{|l|}{ Transport works } \\
\hline H.43 & $\begin{array}{l}\text { Were the communication routes adapted to the means of internal } \\
\text { transport and the cargo transported? }\end{array}$ & & & & & \\
\hline H.44 & Were the roads and passages properly marked and secured? & & & & & \\
\hline I. & \multicolumn{6}{|l|}{ Earthworks } \\
\hline $\mathrm{I} .45$ & $\begin{array}{l}\text { Were the excavation walls adequately protected by lining or slop- } \\
\text { ing? }\end{array}$ & & & & & \\
\hline I.46 & $\begin{array}{l}\text { Were there safe descents to the workplaces, located at a distance } \\
\text { of max. } 20 \mathrm{~m} \text { ? }\end{array}$ & & & & & \\
\hline I.47 & Was the spoil properly stored? & & & & & \\
\hline I. 48 & $\begin{array}{l}\text { Were the earthworks with the use of mechanized equipment car- } \\
\text { ried out in accordance with the health and safety requirements? }\end{array}$ & & & & & \\
\hline
\end{tabular}


Table 1. Questionnaire for researching the perception of occupational health and safety of students of construction faculties

\begin{tabular}{|c|c|c|c|c|c|c|}
\hline No. & Questions about the studied issue & $\sum_{i}^{\infty}$ & 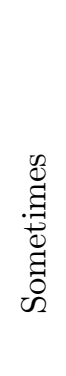 & 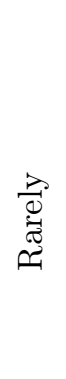 & 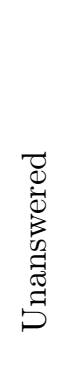 & 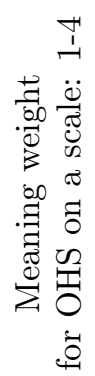 \\
\hline$-1-$ & $-2-$ & $-3-$ & $-4-$ & $-5-$ & $-6-$ & $-7-$ \\
\hline I. 49 & $\begin{array}{l}\text { Has a safe distance for the works to be carried out from the ex- } \\
\text { isting heating, gas etc. networks been defined? }\end{array}$ & & & & & \\
\hline I.50 & $\begin{array}{l}\text { Is the permissible depth of } 1 \mathrm{~m} \text { for a trench with vertical walls } \\
\text { without reinforcements maintained? }\end{array}$ & & & & & \\
\hline I.51 & Was the excavation deeper than $1 \mathrm{~m}$ properly secured? & & & & & \\
\hline $\mathrm{I} .52$ & $\begin{array}{l}\text { Has design documentation been prepared for excavations with a } \\
\text { depth exceeding } 4 \mathrm{~m} \text { ? }\end{array}$ & & & & & \\
\hline $\mathrm{I} .53$ & $\begin{array}{l}\text { Were the spoil and materials stored outside the wedge zone of the } \\
\text { natural fragment of soil, if the excavation walls were not covered? }\end{array}$ & & & & & \\
\hline I.54 & Were descents / entrances to excavations deeper than $1 \mathrm{~m}$ made? & & & & & \\
\hline I.55 & $\begin{array}{l}\text { Was the performance of works in the excavation carried out in } \\
\text { accordance with the health and safety regulations? }\end{array}$ & & & & & \\
\hline $\mathrm{I} .56$ & $\begin{array}{l}\text { Have safe working conditions been agreed with the user of the } \\
\text { high-voltage line during the performance of works with machines } \\
\text { or other devices directly below the line? }\end{array}$ & & & & & \\
\hline J. & Foundation works (carpentry, reinforcement, concrete) & & & & & \\
\hline $\mathrm{J} .57$ & $\begin{array}{l}\text { Were the workers performing the foundation works equipped with } \\
\text { trays for hand tools, preventing the tools from falling out and not } \\
\text { hindering their freedom of movement? }\end{array}$ & & & & & \\
\hline J.58 & $\begin{array}{l}\text { Were ladder carpentry works carried out only up to a height of } 3 \\
\mathrm{~m} ?\end{array}$ & & & & & \\
\hline J.59 & $\begin{array}{l}\text { Was the carpentry work carried out by a team of at least two } \\
\text { people? }\end{array}$ & & & & & \\
\hline J.60 & $\begin{array}{l}\text { During the assembly or disassembly of the formwork, are there } \\
\text { any measures to prevent collapse of the stiffening and expanding } \\
\text { structures? }\end{array}$ & & & & & \\
\hline J.61 & $\begin{array}{l}\text { Did the permanent workshop and reinforcement machines meet } \\
\text { the health and safety requirements? }\end{array}$ & & & & & \\
\hline J.62 & $\begin{array}{l}\text { Were the elements of the reinforcement properly stored, trans- } \\
\text { ported and installed safely? }\end{array}$ & & & & & \\
\hline J.63 & $\begin{array}{l}\text { Was concreting - emptying the containers by pouring the concrete } \\
\text { mix into the formwork, from a height not exceeding } 1 \mathrm{~m} \text { ? }\end{array}$ & & & & & \\
\hline J.64 & $\begin{array}{l}\text { Were the workers carrying out the foundation works out of the } \\
\text { danger zone, e.g. in the work area of a crane or concrete pump? }\end{array}$ & & & & & \\
\hline $\mathrm{K}$. & Concrete works & & & & & \\
\hline K.65 & $\begin{array}{l}\text { When the concrete mixture was delivered by vehicle, was the chute } \\
\text { point equipped with fenders to prevent the vehicle from rolling } \\
\text { away? }\end{array}$ & & & & & \\
\hline K.66 & $\begin{array}{l}\text { While feeding the concrete mixture with the pump, were the work- } \\
\text { ers not working in the danger zone of the pump? }\end{array}$ & & & & & \\
\hline
\end{tabular}


Table 1. Questionnaire for researching the perception of occupational health and safety of students of construction faculties

\begin{tabular}{|c|c|c|c|c|c|c|}
\hline No. & Questions about the studied issue & $\sum_{i}^{\infty}$ & 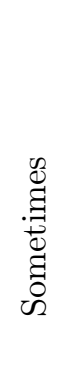 & 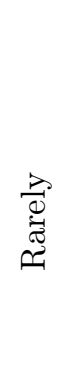 & 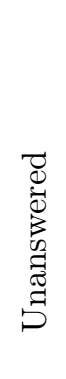 & 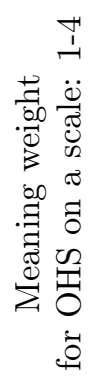 \\
\hline$-1-$ & $-2-$ & $-3-$ & $-4-$ & $-5-$ & $-6-$ & $-7-$ \\
\hline K.67 & $\begin{array}{l}\text { Did the employees comply with the health and safety rules and } \\
\text { regulations when making the concrete mix with a concrete mixer? }\end{array}$ & & & & & \\
\hline L. & Assembly work with the use of a crane & & & & & \\
\hline L. 68 & $\begin{array}{l}\text { Was the crane equipped with a board informing about the per- } \\
\text { missible load? }\end{array}$ & & & & & \\
\hline L. 69 & $\begin{array}{l}\text { Was the crane track (crane workstation) in a proper technical } \\
\text { condition? }\end{array}$ & & & & & \\
\hline L.70 & Were the crane's controls and signals operational? & & & & & \\
\hline L.71 & $\begin{array}{l}\text { Was the proper condition of the crane's lightning protection sys- } \\
\text { tem documented with current measurements? }\end{array}$ & & & & & \\
\hline L.72 & $\begin{array}{l}\text { Was the crane's documentation kept, e.g. a roster book and a } \\
\text { crane inspection book? }\end{array}$ & & & & & \\
\hline L.73 & $\begin{array}{l}\text { Were the crane operator's working standards complied with? } \\
\text { Were the assembly works of steel structures and prefabricated } \\
\text { large-size elements carried out on the basis of the assembly design } \\
\text { and the health and safety environment plan, by employees famil- } \\
\text { iar with the assembly organization instructions and the type of } \\
\text { machines and devices used? }\end{array}$ & & & & & \\
\hline L.75 & $\begin{array}{l}\text { Was it forbidden to stay during the assembly works on the two } \\
\text { lower storeys located directly under the storey to be installed? }\end{array}$ & & & & & \\
\hline L.76 & $\begin{array}{l}\text { Were assembly works made of large / large-block elements carried } \\
\text { out at wind speeds up to } 10 \mathrm{~m} / \mathrm{s} \text { and good visibility? }\end{array}$ & & & & & \\
\hline L.77 & $\begin{array}{l}\text { Was the lifting, guiding and stabilization of the assembled element } \\
\text { carried out in a safe manner? }\end{array}$ & & & & & \\
\hline L.78 & $\begin{array}{l}\text { Was the lifting signal given after people were removed from the } \\
\text { danger zone? }\end{array}$ & & & & & \\
\hline L.79 & $\begin{array}{l}\text { During crane operation, did workers work in the hazardous area, } \\
\text { e.g. under the crane jib? }\end{array}$ & & & & & \\
\hline M. & Finishing works & & & & & \\
\hline M.80 & $\begin{array}{l}\text { Was the air exchange in closed rooms provided for the needs of } \\
\text { work safety? }\end{array}$ & & & & & \\
\hline M.81 & $\begin{array}{l}\text { Were the persons performing the finishing works exposed to noise, } \\
\text { vibration, electromagnetic radiation, dust and gases with intensi- } \\
\text { ties exceeding the limit values? }\end{array}$ & & & & & \\
\hline M.82 & $\begin{array}{l}\text { Was the person working in confined spaces with insufficient oxy- } \\
\text { gen content or agents with concentrations below the limit values } \\
\text { observed and secured to ensure immediate evacuation and effec- } \\
\text { tive assistance? }\end{array}$ & & & & & \\
\hline \multicolumn{7}{|c|}{ Health and safety requirements for employees } \\
\hline N. & Employee qualifications & & & & & \\
\hline
\end{tabular}


Table 1. Questionnaire for researching the perception of occupational health and safety of students of construction faculties

\begin{tabular}{|c|c|c|c|c|c|c|}
\hline No. & Questions about the studied issue & $\sum_{i}^{\infty}$ & 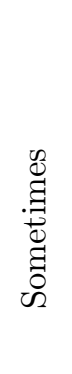 & 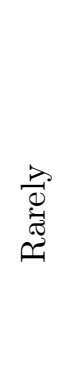 & 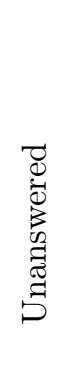 & 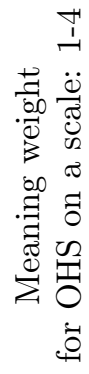 \\
\hline$-1-$ & $-2-$ & $-3-$ & $-4-$ & $-5-$ & $-6-$ & $-7-$ \\
\hline N.83 & $\begin{array}{l}\text { Have the employees been trained in the proper scope of health } \\
\text { and safety? }\end{array}$ & & & & & \\
\hline N.84 & $\begin{array}{l}\text { Did the training courses meet the requirements for the given job } \\
\text { positions? }\end{array}$ & & & & & \\
\hline O. & Medical examination of employees & & & & & \\
\hline O.85 & $\begin{array}{l}\text { Did the employees have current medical requirements that there } \\
\text { are no contraindications to work in the position they hold? }\end{array}$ & & & & & \\
\hline O.86 & Did the employees get regular medical examinations? & & & & & \\
\hline $\mathrm{O} .87$ & $\begin{array}{l}\text { Were preliminary medical examinations carried out before starting } \\
\text { work in a given position? }\end{array}$ & & & & & \\
\hline $\mathrm{O} .88$ & $\begin{array}{l}\text { Was the employee subject to medical checkups in the event of } \\
\text { incapacity for work lasting more than } 30 \text { days, e.g. due to illness? }\end{array}$ & & & & & \\
\hline O.89 & $\begin{array}{l}\text { Were periodic medical examinations carried out in order to deter- } \\
\text { mine the ability to perform work in a given position? }\end{array}$ & & & & & \\
\hline $\mathrm{P}$. & \multicolumn{6}{|l|}{ Occupational health and safety training } \\
\hline P.90 & $\begin{array}{l}\text { Were the workers performing the work subject to general instruc- } \\
\text { tion? }\end{array}$ & & & & & \\
\hline P.91 & $\begin{array}{l}\text { As part of the on-the-job training, have the employees been ac- } \\
\text { quainted with the hazards in their workplaces and the occupa- } \\
\text { tional risks associated with the work they perform, methods of } \\
\text { protection against threats and methods of safe work performance } \\
\text { at a given position? }\end{array}$ & & & & & \\
\hline P.92 & $\begin{array}{l}\text { Did the employees undergo periodic training in the form of briefing } \\
\text { at least once every three years, and once a year when performing } \\
\text { particularly dangerous work? }\end{array}$ & & & & & \\
\hline $\mathrm{R}$. & \multicolumn{6}{|l|}{ Means of personal protection } \\
\hline R.93 & $\begin{array}{l}\text { Did employers provide employees with personal protective equip- } \\
\text { ment against harmful and dangerous factors in every aspect re- } \\
\text { lated to work? }\end{array}$ & & & & & \\
\hline R.94 & $\begin{array}{l}\text { Did the employee have personal protective equipment adapted to } \\
\text { his own body shape? }\end{array}$ & & & & & \\
\hline $\mathrm{R} .95$ & $\begin{array}{l}\text { Did the employee use personal protective equipment (lower and } \\
\text { upper limbs, face and eyes, hearing, respiratory system, measures } \\
\text { to isolate the whole body, work clothes, warning clothing? }\end{array}$ & & & & & \\
\hline R.96 & $\begin{array}{l}\text { Has the employee been informed about the methods of using per- } \\
\text { sonal protective equipment? }\end{array}$ & & & & & \\
\hline S. & \multicolumn{6}{|l|}{ Work positions and processes, risk assessment at work stations } \\
\hline S.97 & $\begin{array}{l}\text { Are dangerous zones (technological openings and other dangerous } \\
\text { places) secured (handrails, protective canopies, etc.) and marked? }\end{array}$ & & & & & \\
\hline
\end{tabular}


Table 1. Questionnaire for researching the perception of occupational health and safety of students of construction faculties

\begin{tabular}{|c|c|c|c|c|c|c|}
\hline No. & Questions about the studied issue & $\sum_{i}^{\infty}$ & 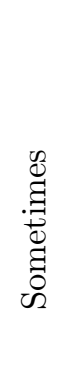 & 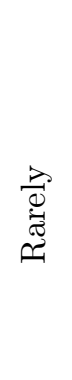 & 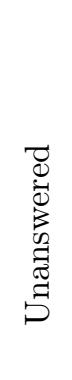 & 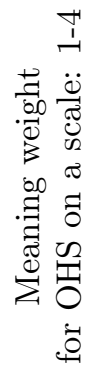 \\
\hline$-1-$ & $-2-$ & $-3-$ & $-4-$ & $-5-$ & $-6-$ & $-7-$ \\
\hline S.98 & $\begin{array}{l}\text { Are workstations in the vicinity of active, overhead power lines } \\
\text { properly secured? }\end{array}$ & & & & & \\
\hline S.99 & $\begin{array}{l}\text { Were the work stations adequately secured against falling objects, } \\
\text { weather conditions and mechanical damage? }\end{array}$ & & & & & \\
\hline S.100 & $\begin{array}{l}\text { Are workstations at heights (edges of open spaces) secured by } \\
\text { applying appropriate collective protection measures? }\end{array}$ & & & & & \\
\hline S.101 & $\begin{array}{l}\text { Has an occupational risk assessment been performed at work- } \\
\text { places? }\end{array}$ & & & & & \\
\hline T. & \multicolumn{6}{|l|}{ Nuisance, harmful and dangerous factors at the work stations } \\
\hline T.102 & Were there any harmful and dangerous factors at the exhibit? & & & & & \\
\hline T.103 & $\begin{array}{l}\text { Has the employee been informed about the occupational risk re- } \\
\text { lated to the work performed by him and about the principles of } \\
\text { protection against hazards in this position? }\end{array}$ & & & & & \\
\hline T.104 & Did the employer provide work clothes and footwear? & & & & & \\
\hline T.105 & $\begin{array}{l}\text { Did the employees use work clothes and footwear provided by the } \\
\text { employer? }\end{array}$ & & & & & \\
\hline T.106 & Were the employees equipped with personal protective equipment? & & & & & \\
\hline T.107 & Did the employees use personal protective equipment? & & & & & \\
\hline $\mathrm{U}$. & \multicolumn{6}{|c|}{ Safety and health protection of students working during the COVID-19 epidemic } \\
\hline \multicolumn{7}{|c|}{ Actions to ensure physical distance in the workplace } \\
\hline U.108 & $\begin{array}{l}\text { Has an action plan been developed at the level of top construc- } \\
\text { tion management to reduce the risk of contracting SARS-CoV- } 2 \\
\text { coronavirus at work? }\end{array}$ & & & & & \\
\hline U.109 & $\begin{array}{l}\text { Does management and employee representatives, occupational } \\
\text { medicine physician and OSH specialists contribute to the devel- } \\
\text { opment of the action plan? }\end{array}$ & & & & & \\
\hline U.110 & $\begin{array}{l}\text { Are those developing the action plan provided with the necessary } \\
\text { information about the coronavirus and the laws in force during } \\
\text { the outbreak, and is this information kept up to date? }\end{array}$ & & & & & \\
\hline U.111 & $\begin{array}{l}\text { Are the types of work that are most likely to be contaminated on } \\
\text { the site identified and measures to reduce this likelihood identi- } \\
\text { fied? }\end{array}$ & & & & & \\
\hline U.112 & $\begin{array}{l}\text { Does the action plan specify what measures will be implemented } \\
\text { for the different types of work, and does it specify deadlines for } \\
\text { their implementation and those responsible for implementation? }\end{array}$ & & & & & \\
\hline U.113 & $\begin{array}{l}\text { Does the action plan set out rules for reducing the mental burden } \\
\text { from SARS-CoV-2? }\end{array}$ & & & & & \\
\hline
\end{tabular}


Table 1. Questionnaire for researching the perception of occupational health and safety of students of construction faculties

\begin{tabular}{|c|c|c|c|c|c|c|}
\hline No. & Questions about the studied issue & $\sum_{i}^{\infty}$ & 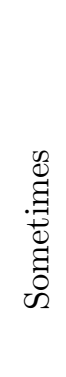 & 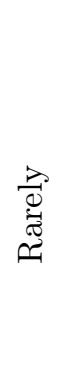 & 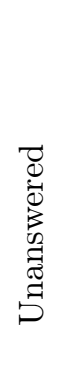 & 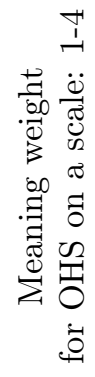 \\
\hline$-1-$ & $-2-$ & $-3-$ & $-4-$ & $-5-$ & $-6-$ & $-7-$ \\
\hline U.114 & $\begin{array}{l}\text { Does the action plan set out rules for communicating about the } \\
\text { actions being implemented to reduce the likelihood of contracting } \\
\text { SARS-CoV-2 at work? }\end{array}$ & & & & & \\
\hline U.115 & $\begin{array}{l}\text { Does the action plan lay down rules for dealing with suspected } \\
\text { contamination? }\end{array}$ & & & & & \\
\hline U.116 & $\begin{array}{l}\text { Is the action plan updated, taking into account the changing sit- } \\
\text { uation, knowledge and legal regulations? }\end{array}$ & & & & & \\
\hline \multicolumn{7}{|c|}{ Actions to ensure physical distance in the workplace } \\
\hline U.118 & Are the work stations located so that they are at least $1.5 \mathrm{~m}$ apart? & & & & & \\
\hline U.119 & $\begin{array}{l}\text { Are the workplaces positioned so that staff and students have their } \\
\text { backs to each other as much as possible? }\end{array}$ & & & & & \\
\hline U.120 & $\begin{array}{l}\text { Are there any rules for the use of communication routes ensuring } \\
\text { that the distance between the people who use them is at least } 1.5 \\
\mathrm{~m} ?\end{array}$ & & & & & \\
\hline U.121 & $\begin{array}{l}\text { Are there any rules for registering entry / exit to / from work (e.g. } \\
\text { signing a list) ensuring a } 1.5 \mathrm{~m} \text { distance between employees? }\end{array}$ & & & & & \\
\hline U.122 & $\begin{array}{l}\text { Are there any rules for the use of places customarily intended } \\
\text { for many employees and students (e.g. dean's office, office, tool } \\
\text { dispensing points) ensuring that a distance of } 1.5 \mathrm{~m} \text { between em- } \\
\text { ployees staying there is kept? }\end{array}$ & & & & & \\
\hline U.123 & $\begin{array}{l}\text { Have rules for the use of social and hygienic-sanitary rooms been } \\
\text { defined, ensuring that a distance of } 1.5 \mathrm{~m} \text { between employees and } \\
\text { students staying there is kept? }\end{array}$ & & & & & \\
\hline U.124 & Are employees allowed to work remotely where possible? & & & & & \\
\hline \multicolumn{7}{|c|}{ Performing works that require direct contact } \\
\hline U.125 & $\begin{array}{l}\text { Is there a permanent composition of teams carrying out work re- } \\
\text { quiring direct contact between employees and students? }\end{array}$ & & & & & \\
\hline U.126 & $\begin{array}{l}\text { Whether in workplaces that require long, direct contact with peo- } \\
\text { ple from outside the University (e.g. customers, suppliers) there } \\
\text { are partitions (transparent screens, e.g. glass or plastic) to sepa- } \\
\text { rate workers from these people? }\end{array}$ & & & & & \\
\hline U.127 & $\begin{array}{l}\text { Has there been a requirement to limit the time of direct contact } \\
\text { between employees, students and people outside the workplace } \\
\text { (e.g. customers, suppliers) to max. } 15 \text { min? }\end{array}$ & & & & & \\
\hline U.128 & $\begin{array}{l}\text { Has a requirement been introduced for the use of personal pro- } \\
\text { tective equipment (protective masks, helmets, disposable gloves, } \\
\text { goggles, as well as gowns and overalls) by employees, students } \\
\text { performing work requiring long direct contact with people from } \\
\text { outside the university (e.g. customers, suppliers)? }\end{array}$ & & & & & \\
\hline
\end{tabular}


Table 1. Questionnaire for researching the perception of occupational health and safety of students of construction faculties

\begin{tabular}{|c|c|c|c|c|c|c|}
\hline No. & Questions about the studied issue & $\overbrace{i}^{\infty}$ & 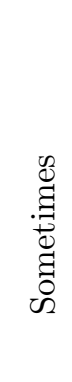 & 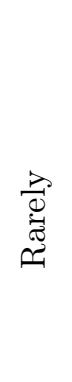 & 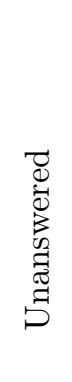 & 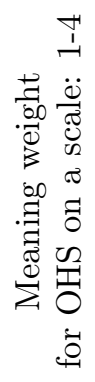 \\
\hline$-1-$ & $-2-$ & $-3-$ & $-4-$ & $-5-$ & $-6-$ & $-7-$ \\
\hline U.129 & $\begin{array}{l}\text { Have meetings and conferences requiring the physical presence of } \\
\text { employees or students been replaced with tele- or videoconfer- } \\
\text { ences? }\end{array}$ & & & & & \\
\hline \multicolumn{7}{|c|}{ Part B } \\
\hline \multicolumn{7}{|c|}{ Assessment of actions and behavior of direct management, e.g. works manager } \\
\hline U.130 & Did the management meet the safety and health requirements? & & & & & \\
\hline U.131 & $\begin{array}{l}\text { Did the management meet the safety and health protection re- } \\
\text { quirements for the workplace? }\end{array}$ & & & & & \\
\hline \multicolumn{7}{|c|}{$\begin{array}{c}\text { Assessment of the role and significance of factors influencing safety and health protection } \\
\text { at construction workplaces }\end{array}$} \\
\hline \multirow[t]{5}{*}{ W.132 } & What factors will be decisive when taking up a new/changing job: & & & & & \\
\hline & - safe and healthy working conditions & & & & & \\
\hline & - remuneration & & & & & \\
\hline & - job security & & & & & \\
\hline & - work hours & & & & & \\
\hline W.133 & $\begin{array}{l}\text { Do you think that ignorance and non-compliance with health and } \\
\text { safety rules and regulations may cause a bad condition or deteri- } \\
\text { oration of health or even death? }\end{array}$ & & & & & \\
\hline W.134 & $\begin{array}{l}\text { Does informing employees about safety and health protection dur- } \\
\text { ing work affect the level of health and safety at work? }\end{array}$ & & & & & \\
\hline W.135 & $\begin{array}{l}\text { Are the health and safety conditions at work being / will / will } \\
\text { be improved? }\end{array}$ & & & & & \\
\hline
\end{tabular}

In the future, both the map and the questionnaire can be extended by one more point $\mathrm{W}$ - the area of financial security in the field of social sciences in the discipline of economics and finance, whose task will be to analyze the feasibility of each point from the structure of the ohs knowledge map (A - U points), taking into account sources of their financing. This would be another new area to research. Based on the widely available information published on the subject of economic and financial situation of business entities (e.g. published financial statements in the Court and Economic Monitor, or audit documentation of the auditor of selected entities), it would be possible to analyze the financial security of the discussed issues.

\section{Conclusions}

To develop the structure of the ohs knowledge map, national legal regulations, European Union directives and guidelines of the International Labor Organization on safety and health protection in construction as well as the practical experience of the authors were used. The universal aspect of knowledge and its components was assumed. This assumption results from the specificity of construction works, the variety of construction objects and the complexity 
of the investment process in construction and allows for its quick adaptation in all organizations participating in the individual stages of the construction investment process. Questionnaires will be used to assess the level of knowledge and awareness of students about the risks in the area of safety and security in the construction industry using the ohs knowledge map. The results will allow to plan activities increasing the level of students' knowledge in the field of ohs, as well as link this field of knowledge in the future with the basic knowledge outlined by the field of social sciences. The latter is the discipline of economics and finance, and therefore necessary for a comprehensive analysis of the issues specified in the ohs knowledge map subject to analysis in the way specified in the questionnaire, so that after starting work in the construction industry, they will be familiar with the health and safety regulations.

\section{References}

1. Anna. Rewizja finansowa a bezpieczeństwo obrotu gospodarczego in Praktyczne uwarunkowania bezpieczeństwa europejskiego (ed Kuczyńska-Cesarz) (Wojskowa Akademia Techniczna, 2017), 272.

2. Baltic sea trade union network on health and safety'jako głos w społecznym dialogu na temat bezpieczeństwa $i$ ochrony zdrowia Wybrane aspekty zarządzania wiedzą w organizacji (Polskie Zrzeszenie Inżynierów i Techników Sanitarnych, Poznań, 2005).

3. Baryłka, A. Obiekty budowlane jako przedmioty procesu budowlanego (inwestycyjnego i eksploatacyjnego). Inżynieria Bezpieczeństwa Obiektów Antropogenicznych (2019).

4. Baryłka, A. Wprowadzenie do zagadnienia problemów techniczno-prawnych eksploatacji obiektów budowlanych. Inżynieria Bezpieczeństwa Obiektów Antropogenicznych (2019).

5. Baryłka, A. \& Obolewicz, J. Empirical veryfication of worksafety evoution. Modern Engineering, 125-130. ISSN: 2450-5501 (3 2020).

6. Baryłka, A. \& Obolewicz, J. Safety and health protection (SHP) in managing construction projects. Inżynieria Bezpieczeństwa Obiektów Antropogenicznych. ISSN: 2450-1859 (1 2020).

7. Baryłka, A. \& Obolewicz, J. Technical diagnosis as an important engineering tool of electrical power facilities. Rynek Energii, 65-70 (6 2020).

8. Dyrektywa CEE 92/57 w sprawie wdrożenia minimalnych wymagań bezpieczeństwa $i$ ochrony zdrowia na tymczasowych lub ruchomych budowach (ósma szczegótowa dyrektywa w rozumieniu art. 16 ust. 1 dyrektywy 89/391/EWG)

9. Ejdys, J., Lulewicz, A. \& Obolewicz, J. Zarzadzanie bezpieczeństwem w przedsiębiorstwie (Wydawnictwa Politechniki Białostockiej, Białystok, 2008).

10. Hoła, B., Polak, A., Gawron, K., Sawicki, M. \& Gronowicz, W. Mapa Wiedzy w zarządzaniu przedsiębiorstwem budowlanym. Przeglad budowlany, 47-51 (2012).

11. Jashapara, A. Zarzadzanie wiedza ISBN: 9788320820928 (2014).

12. Jemielniak, D. \& Koźmiński, A. K. Zarządzanie wiedza ISBN: 978-83-264-3583-6 (Wolters Kluwer Polska, 2012).

13. Kuczyńska-Cesarz, A. Concept of a selected cost account and decision-making processes in a enterprise. Nowoczesne Systemy Zarzadzania 13, 215-229 (4 2018).

14. Obolewicz, J. Wpływ wejścia Polski do Unii Europejskiej na ochronę pracy w sektorze budowlanym. Zarządzanie i Edukacja 63 (2009).

15. Obolewicz, J. Koordynacja bezpieczeństwa i ochrony zdrowia w budowlanym procesie inwestycyjnym. Przeglad Budowlany 82, 60-63 (2 2011).

16. Obolewicz, J. Demoskopia bezpieczeństwa i ochrony zdrowia przedsięwzięć budowlanych (Oficyna Wydawnicza Politechniki Białostockiej, Białystok, 2018).

17. Obolewicz, J. Knowledge map as a tool for work safety and health protection in engineering construction project 2020 .

18. Obolewicz, J., Baryłka, A., Jaros, H. \& Ginda, G. A map of knowledge and its importance in the life cycle of a constructiom object. Inżynieria Bezpieczeństwa Obiektów Antropogenicznych. ISSN: 2450-1859 (2 2020).

19. Pellicer, E., Yepes, V., Teixeira, J. M., Moura, H. \& Catalá, J. Zarządzenie budowa (BIBLIOTEKA MENEDŻERÓW BUDOWLANYCH, 2008).

20. Polak, A. Nauczanie organizacji przedsiębiorstw za pomocą mapy wiedzy. Przegląd Budowlany, 10-13 (2011).

21. Prawo budowlane $z$ dnia 7 lipca 1994r. Stan prawny na 20 lipca $2020 \mathrm{r}$

22. Silva, A. \& Šteinbuka, I. Health and safety at work in Europe (1999-2007). A statistical portrait ISBN: 978-9279-14606-0 (2010).

23. Szczerbak, M. Audyt wewnętrzny w ocenie skuteczności kontroli, procesów zarządzania ryzykiem i ładu korporacyjnego. Ekonomika i Organizacja Przedsiębiorstwa, 67-81. ISSN: 0860-6846 (1 2016).

24. Szczerbak, M. Funkcje rachunkowości w XXI wieku 2021. 